5. Зеленько О.А. Психологічне обгрунтування трансформації вищої школи України. / Науковий вісник НУБіП України. - Серія «Педагогіка, психологія, філософія». - № 239. - Київ, 2016. - С. 84-94.

6. Зеленько О.А. Регіональний гуманітарний (елітний) університет / Наукові записки НДУ ім. М. Гоголя, Психолого-педагогічні науки, випуск 2, Ніжин, 2020, С. 139-145.

7. Маслоу А. Мотивация и личность. К.: PSYLIB, 2004, 256 с.

8. Фрейд 3. Будущность одной иллюзии // Сумерки богов. М.: Политиздат, 1990, 398 с.

9. Фромм Э. Анатомия человеческой разрушительности. М.: ЭКСМО, 2017, $736 \mathrm{c.}$

10. Фромм Э. Бегство от свободы. М.: Академкнига, 2017, 288 с.

DOI https://doi.org/10.30525/978-9934-588-80-8-1.10

\title{
САМОТНІСТЬ ОСОБИСТОСТІ ЯК ПСИХОЛОГІЧНА ПРОБЛЕМА
}

\author{
Іваненко Б. Б. \\ кандидат психологічних наук, \\ дочент кафедри загальної психології \\ Київський національний університет імені Тараса Шевченка \\ м. Київ, Украӥна
}

Метою роботи є розгляд психологічних чинників, які призводять до небажаного почуття (стану) самотності дорослої особистості.

У сучасному суспільстві, незважаючи на тенденції індивідуалізації, розуміння «самотньої людини» пов'язанє із стереотипним сприйманням, міфами, упередженим ставленням. Свідомий вибір дорослої людини на користь самотнього життя нерідко розцінюється оточуючими як вимушений стан, що викликає страждання. Так, депресивні розлади, самодеструктивну поведінку, всякого роду залежності, на які стражає людина, намагаються пояснити іiї станом самотності. Інший стереотип - підтримка враження, що як тільки людина знайде партнера, здійснить вихід із самотнього життя, іiі психологічний стан покращиться, вона стане щасливою. Проте практика психологічної роботи доводить: схильність переживати почуття самотності глибоко вкорінена 3 дитинства, витоки самотнього стану всупереч бажанням людини - в психотравмах дитинства, які спричиняють страх емоційної 
близькості з людьми, стійку тенденцію жити самотнім життям, яке, проте, не вдовольняє. Водночас ще у дитинстві людина отримує від оточення, соціальних установ, з казок та фільмів, від близьких людей установку на те, що жити одному - дивно, неправильно, небезпечно. Відбувається загострення внутрішньої суперечності, на одному полюсі якої - глибинна туга за близькими стосунками, сильне бажання не бути самотнім, не залишатися на самоті, а на іншому - страх зближення зі значимим іншим; блокування, переривання контактів, які потенційно можуть стати близькими; саморуйнівна, самодеструктивна поведінка, що проявляється у залежностях як заміщенні близького контакту.

Словник психолога-практика подає наступне визначення самотності: «один з психогенних факторів, що впливає на емоційний стан людини, яка знаходиться в змінних (незвичних) умовах ізоляції від інших людей [5, с. 444]. Це і соціально-психологічне явище, й емоційний стан, пов'язаний 3 відсутністю близьких, позитивних емоційних зв'язків 3 людьми, зі страхом їх втрати в результаті соціальної ізоляції.

3 точки зору психології, той, кому не нудно 3 самим собою, $€$ цілісною особистістю, не схильною до руйнівної співзалежності. Е. Кляйненберг пояснює: «Важливий не факт, що людина живе одна, а те, чи відчуває вона себе самотньою» [2, с. 18]. Дослідження показують, що життя самотніх людей більш насичене, ніж одружених, адже самотній стиль стиль життя дозволяє відчути користь здорового егоїзму, мати час для самопізнання.

Почуття самотності виникає тоді, коли «живі» зв'язки з людьми перериваються. Однак на серйозну психологічну проблему вказує відчуття, що стан самотності виснажує, триває у часі, не піддається контролю й регуляції. К. Ізард стверджує: «Психологічна ізоляція може набувати різних форм, це може бути нездатність до спілкування, до щирого вираження своїх почуттів, невміння завоювати симпатію оточуючих. У людини при цьому відсутнє почуття приналежності, вона почуває себе самотньою, покинутою людьми. У неї не задоволена потреба належати кому-небудь... Найчастіше, залишаючись на самоті, людина відчуває загрозу своїй безпеці, але варто ій опинитися серед людей, як страх відступає» [1, с. 87].

Самотня людина характеризується винятковою зосередженістю на самій собі, на своїх особистих проблемах й внутрішніх переживаннях, живе немов би у своєму світі, заглиблена у себе і має труднощі у тому, щоб «плавати на поверхні реальності» - підтримувати невимушені контакти з іншими людьми. Дослідження доводять, що, спілкуючись 3 іншими, самотні люди більш песимістично налаштовані, говорять про 
себе, часто змінюють тему розмови й не одразу реагують на висловлювання партнерів по спілкуванню. В умовах тривалого позбавлення контакту з людьми потреба в спілкуванні загострюється. Людина може персоніфікувати предмети, тварин, створювати уявних партнерів. Так, коли людина втрачає близького внаслідок його смерті й відчуває нездоланне почуття туги, пустки й самотності, виникає потреба у «внутрішньому діалозі з померлим близьким».

Аналіз наукових джерел 3 проблеми самотності та результати психологічної практики дозволяють зробити напступні узагальнення щодо психологічного феномену самотності: 1) Люди використовують різні стандарти для визначення почуття самотності. Розуміння висловлювання «Я відчуваю себе самотньо» може бути багатозначним. 2) Люди прагнуть пояснити причини самотності. 3) Емоційна травма дитинства породжує чутливість до самотності в дорослому віці. Для психотравмуючої ситуації самотності характерне відчуття нудьги й печалі. 4) Переживаючи самотність як психологічну проблему, особистість перебуває в психотравмуючій ситуації, проте фактично відтворюється психотравма дитинства. 5) Людина заповнює самотність двома способами: діяльність або фантазія. 6) Відчуття самотності виникає тому, що людина порівнює себе з навколишнім соціумом і «не співставляється» 3 ним, відчуває свою «іншість», відмінність, невідповідність ухваленим у соціумі стандартам успішного життя й самореалізованої особистості. 7) Тимчасове, минуще відчуття самотності - ностальгічне самотність сприятлива для митців, оскільки дарує натхнення. 8) Одна 3 причин розповсюдженості самотності - в суспільстві впродовж твалого історичного періоду формувався культ страждання, люди не вміють радіти життю. 9) Самотність - це емоційна депривація, голод по спілкуванню, нестача того чи іншого виду інформації або вражень. 10) Самотність - це зворотній бік «самостійності лідера». 11) Люди відчувають сором, визнаючи власну самотність, оскільки вони сприймають ії як життєвий неуспіх. 12) Подолання самотності часто здійснюється ціною різних залежностей. 13) Почуття самотності зростає, коли людина не вміє відчувати і розуміти власні потреби: шукає не те, чого їй бракує, намагається заповнити у житті зовсім не ту нішу.

Психоаналітичні та глибинно-психологічні дослідження (А. Міллер, О. Ранк, М. Кляйн, Г. Салліван, Б. Фурст, А. Фрейд, К. Хорні, Х. Хартман, Б. Хеллінгер, Т. Яценко та ін.) доводять, що вже в ранньому дитинстві включаються найрізноманітніші захисні механізми для блокування проявів почуття самотності. Це відбувається за умови, коли пережите в дитинстві в батьківському вихованні почуття 44 
самотності не отримало належного виходу, а отже, призвело до відчуження, ізоляції людини від самої себе. У даній ситуації людина залишається фіксованою на пережитій травмі, їй ніяк не вдається внутрішньо відділитися від батьків. У зрілому віці людина стає залежною від людей, що заміщують батьків, що нерідко стає основою співзалежних стосунків. Так, А. Міллер наголошує: «Поряд зі звичайним запереченням ми зустрічаємося з постійною виснажливою боротьбою, спрямованою на те, щоб за допомогою замінників (наркотики, спілкування в різного роду групах, культові обряди будьякої орієнтації, сексуальні збочення) задовольнити витіснені в несвідоме і вже деформовані потреби. Багато хто вдається до інтелектуальних способів... Включення цих захисних механізмів супроводжується витісненням в несвідоме спогадів про первинну ситуацію $\mathrm{i}$ пов'язані з нею почуття» [3, с. 48]. Почуття глибокої самотності у ранньому дитинстві призводить до того, що людина не може покластися на власні почуття, оскільке не знає своїх істинних потреб (у тому числі і потреби не бути самотнью та шляхів іiі досягнення), $\epsilon$ надзвичайно далекою від самої себе.

Глибиний та екзистенційний чинник самотності - екзистенціальна провина за неможливість повного злиття з іншою людиною. Людина не може подивитися на світ очима іншої людини, не може відчути те саме, що інший, ці почуття лежать в основі екзистенціальної відособленості самотності. Ця відокремленість створює нездоланний бар'єр і конфлікти між людьми (Р. Мей).

К. Ізард називав природньою причиною самотності дитини загрозу позбавлення батьківської любові. Він вважав, що батьківські покарання (передусім за почуття печалі) формують в дитячій психіці очікування болю, покарання й страх самотності. Вмикається деструктивний механізм переживань: ситуація загрози позбавлення батьківської любові - переживання печалі - страх розлуки й самотності - очікування покарання за ці почуття. Крім того, дитина яскраво уявляє самотність та відчуття болю, яке наступить в результаті втрати комфорту, радості й збудження, які забезпечував йому батько або інша значима людина [1].

Питання, чи позбавляє інтернет-меража від гострого почуття самотності, залишається відкритим. У своїй книзі Mixed Feeling журналістка Сара Рафаель пише: «Я щиро хочу вірити в позитивну силу соціальних мереж, у те, що вони можуть бути інструментом колективної справедливості.. що вони працюють як глобальна сітка, об'єднуюча ізольваних індивідів, які шукають почуття спільності онлайн» [4, с. 69]. Зрозуміло одне: можливість спілкування в інтернет- 
мережі пом'якшує внутрішню суперечність між прагненням до людей й страхом зближення у самотньої людини, дає можливість свідомо символічно заміщувати брак психологічної близькості.

Отже, основні чинники почуття самотності: екзистенційні (принципова неможливість повного злиття 3 іншим й самотнійсть як екзистенційна даність), глибинні (психотравми дитинства), ситуативні (вимушена ізоляція; свідомий вибір на користь життя соло).

\title{
Література:
}

1. Изард К. Психология эмоций / К. Изард; пер. с англ. К. Э. Изард. - СПб.: Питер, 1999. - 460 с.

2. Кляйненберг Э. Жизнь соло: новая социальная реальность. Москва : Альпина Пабликшер. 2014. 284 с.

3. Миллер А. Драма одаренного ребенка и поиск собственного «Я» / А. Миллер. - М.: Академический Проект, 2001. - 144 с.

4. Симада Н., Рафаэль С. Смешанный чувства: изучение эмоционального воздействия наших цифровых привычек. Мельбурн : Quadrille. 2019. 256 c.

5. Словарь психолога-практика / сост. С. Ю. Головин. - 2-е изд., перераб. и доп. - Мн.: Харвест, 2003. - 976 с.

DOI https://doi.org/10.30525/978-9934-588-80-8-1.11

\section{РОЛЬ ПСИХОЛОГА У ПРОЦЕСІ РЕАБІЛІТАЦІЇ ОСІБ ІЗ НАРКОТИЧНОЮ ТА АЛКОГОЛЬНОЮ ЗАЛЕЖНІСТЮ}

\author{
Козира П. В. \\ кандидат психологічних наук, \\ доиент кафедри психології факультету психологіі \\ Львівський державний університет внутрішніх справ \\ м. Львів, Україна
}

Діяльність психолога у закладах для реабілітації осіб із наркотичною та алкогольною залежністю можна порівняти із роботою педагога у закладах освіти, адже ,так само, як педагог повинен надати учням певні базові знання та навички, так і психолог повинен показати узалежненим інший шлях, ознайомити із основними принципами руху до тверезості, який після завершення процесу реабілітації кожен узалежнений повинен розвивати самотужки, у групах 3 іншими 